\author{
DANUTA GWIZDALANKA \\ https://orcid.org/0000-0002-7653-4848 \\ Poznań, Freelance author
}

\title{
Musicians Move About
}

BOOK REVIEW: Renata Suchowiejko, Muzyczny Paryż à la polonaise w okresie międzywojennym. Artyści - wydarzenia - konteksty, Kraków: Wydawnictwo Księgarnia Akademicka 2020.

Musicians move about. In their youth they do so in order to gain professional skills, then they wander in search of audiences that will allow them to practise successfully their chosen profession. The directions of these movements and their nodal points depend on demographics, on economic potential, on what we describe as cultural policy, but also on coincidences and magnetic personalities. That should be enough on the subject of a 'general theory of musicians' migrations', and to those interested in details I recommend the latest book by Renata Suchowiejko, Muzyczny Paryż à la polonaise w okresie międzywojennym. Artyści - wydarzenia - konteksty [Musical Paris à la polonaise during the interwar period. Artists - events - contexts]. A mouthful of a title but an accurate one, since the contents deliver what is promised, and do so in a manner that makes reading it a pleasure.

This period is not a 'blank space' in our historiography. Rather, I would say - and Suchowiejko also makes this claim on a number of occasions - it became a 'golden space'. After all, when writing a textbook on the history of music I myself offered my students the pronouncement: 'The concerts systematically organised by the Association [of Young Polish Musicians in Paris] were of a high standard and evoked much interest'. Now, having read Musical Paris à la polonaise I would put it differently. I would also include a number of conclusions that come to mind while reading since the author, in explaining the presence of Polish music in interwar Paris, also illuminates the functioning of mechanisms in artistic life that to a significant degree are also relevant today. In a flood of texts by authors who dwell on more or less contrived subjects and lofty suppositions regarding composers' intentions, and which for various reasons now feature prominently in our musicography, monographs that describe the real world and are based on sound research are particularly valuable.

In the introduction, or Preludium [Prelude], the author admits that when taking on this subject she could not complain of scarcity of material; rather, of 
its excess. From the vast amount of information she had to extract the fraction concerned with the musicians from Poland, since the research behind the book is based on searches through musical and cultural-artistic periodicals, as well as the relevant columns in the daily press. It also makes use of concert programmes and archival Polish and French materials; we can even see some of them, used as iconography. The author had plenty to choose from in composing the varied and often surprising picture of the times and the people, but she is to be commended for not having drowned in that ocean of sources, taking the readers with her; instead, she has given the whole a sensible framework with absorbing dramatic structure. This means that we start with that which drew the greatest interest of public opinion and the media, and end by learning the behind-the-scenes mechanisms that influenced the direction of that interest.

The first part paints the portraits of four stars: starting with Ignacy Jan Paderewski, generally recognised still today, to the largely forgotten Wanda Landowska. We then follow the main aspects of Polish presence in the French musical life, stemming from individual commitments and diplomatic initiatives. The third part confronts the legend of the Association of Young Polish Musicians with documents and facts. The fourth part develops two threads in parallel: that of political motivation for supporting music, and the activities of specific individuals enmeshed with it - after all, politics is an activity always carried out by someone. And so, from various perspectives, we learn about the circumstances surrounding the entry of Polish music into the concert life of Paris. Sometimes it happened, as it were, in passing, at other times as a result of purposeful efforts.

Even though the subject is the interwar period, it is Fryderyk Chopin's name that appears most frequently. As we read on many occasions, in the minds of French music lovers Chopin was Poland and Poland was Chopin (this is the case in Japan and China today, and organisers of various projects in these countries know that, instead of using the concept of 'Poland', not very meaningful for the audiences there, it is better to announce the event as 'from the land of Chopin'). However, this is not a history of music (or, to be more precise, innovation in music, because this is how things usually turn out), which means that while the book reveals the circumstances in which many excellent works were created that are still performed today, in this monograph composers are in a minority. As happens in real musical life, dominated by performers.

The story begins with the brightest star, Paderewski. Information about his concert tours in France is supported by extensive quotations from local press (the originals are shown as illustrations and selected articles are translated at length). Having already produced a work on the media image of Henryk Wieniawski, the author successfully meets the current challenge. However, while reading this chapter I came to the conclusion that the author must be also a very tactful or very methodologically disciplined person, since personally I could not help but put to the reader the following provocative question: why did Paderewski represent Poland in Paris, but no longer performed in Poland? What was the reason that the Poles were only able to hear him play on the radio, and only when it happened to broadcast his recitals from abroad? But that of course involves Polish-Polish relationships, and not necessarily those concerning music... 
I was somewhat anxious when beginning to read about the second portrait. I was afraid to find something that would require adjustments to the text of my book on Szymanowski, and that had just gone to the typesetters. Fortunately this was not necessary although, were I to write about Szymanowski's links with the Parisian musical community today, I would certainly make use of the information in that chapter. For example, the metaphors about Szymanowski's music in the quoted texts, while in keeping with the spirit of the French language, might have turned their subject's head and given rise to expectation of similar homage in his homeland. Szymanowski is described not just as the 'new Chopin' but even as the 'messiah of Polish music'. So I use this opportunity to agree with the author's conclusion that the comparisons used in these texts (e.g., 'a kind of Scriabin'), often quoted later to accuse critics of not recognising Szymanowski's individuality, were a natural reaction to first contact with his music. It cannot have been easy to discern the nature of his individuality, apparently so obvious for us now, but not until after the passing of many years. This chapter gives us one of the many details that help us to imagine the extent of the phenomenon that is Suchowiejko's subject of research: the richness of concert life. During the $1927 / 1928$ season nearly fifteen hundred concerts took place. Ten years later there was a clear decline, but even so more or less a thousand are recorded. A valuable supplement to comments on the reception of Szymanowski's music is a guide to the most important location on the musical map of Paris. Such concrete details tell the reader which concert halls hosted truly prestigious events, and where people met in their own circles. Moreover, knowing the names and addresses of these halls means that one can find and virtually 'enter' them on the internet.

Maria Modrakowska is the heroine of the third portrait. Her career began as spectacularly as it ended. It ended firstly for personal reasons: she started a family, and then for reasons beyond her control, as the war started and swept away the world in which she already held an exalted position. We learn of the circumstances which allowed the star of this 'Polish Melisande' to burst into brilliance on the firmament of the musical life of Paris, and we find out how she inspired Francis Poulenc to write Eight Polish songs. Reading about the 'enchantress from Saint-Leu', i.e., Landowska, one wants to appeal for someone to at last write a book that is worthy of her qualities and achievements. In this chapter Suchowiejko draws a picture of someone in many ways exceptional. It leads one to conclude that Landowska was an excellent ambassador not only for early music, but also for Polish music, making Parisians aware that Polish music did not begin with Chopin. As an addition to these four stellar portraits we receive a selection of items from the French press recording the appearances of Polish musicians. It includes both those whose memory is still alive, such as Leopold Godowski and Artur Rubinstein, and those who are forgotten and also very diverse, such as for example Marya Freund or Ganna Walska (Walska's life story is a ready-made film scenario).

The next section of the book opens with a presentation of the activities of an enthusiast, Édouard Ganche. His adoration of Chopin provided a stimulus for interest in Polish music in general (I would add at this point that, on a more 
modest scale but in a similar way, Helena Caselli expressed her feelings for Szymanowski: for the love of him she helped his whole circle, not excluding the young composers). The name of Ganche also weaves through reports from the Festival of Polish Music in 1925 and the celebrations of the hundredth anniversary of Chopin's arrival in France, commemorated during the 1931/1932 season by events promoting Polish music in Paris, and organised owing to the increasingly effective foreign cultural policy. On the other hand, when reading about the appearance of the Polish Ballets during the celebrations of closing the World Exhibition in 1937, we return to the mechanism presented at the very beginning of this volume; the person responsible for creating the degree of interest in this performance was Bronisława Niżyńska, well known to Parisian audiences. Much of this chapter is taken up by extensive press reports. Again, as in the case of Szymanowski, compliments are shown side by side with critical remarks. The author explains here why in Poland at that time only the enthusiastically supportive voices were quoted, and the picture of Polish music abroad was then based on these opinions: they provided the public opinion with the rationale for this whole enterprise, in some ways quite overwhelming and for this reason quite fiercely criticised at home.

The third part is devoted to the Association of the Young Polish Musicians in Paris. To start with, Suchowiejko reminds us that a legend has grown around the Association, and then proceeds to submit this myth to a forensic examination. She analyses documents and approaches memoirs and anniversary reflections with the caution of a true researcher. And along the way she notes something which usually escapes musicologists who focus on the works themselves. The ambitions of the performers, members of that Association, clearly diverged from the expectations of the composers. Violinists and pianists wanted to perform repertoire that was recognised, and that allowed them to impress with their artistic craftsmanship. On the other hand, composers were looking for promoters of their music, yet there were not many eagerly waiting for it, which meant that the immediate interests of these groups did not converge.

Suchowiejko on many occasions draws attention to the fact that in Polish musicography, for a variety of reasons, some phenomena were idealised and it is time to look at them with a fresh eye. So it is a good thing that she keeps explaining why some activities were successful while others were doomed to failure. Writing about the Association she shows how a superb idea was born, and how it was later amended by reality. We learn about the living conditions of the scholarship beneficiaries at that time (it would be interesting to learn how today's beneficiaries of the Erasmus programme react to this text). It is clear that the author, who had previously looked at music from the perspective of the performer, notices issues alien to those writers who specialise in analysing and interpreting scores. Here we get concrete details, some as distant from actual music as financial reports - but always with an explanation why it is worthwhile to learn about them. In the descriptions of concert activities she confronts the reality with 'creative reporting' and emphasises that such 'reporting statistics' were necessary for 'promotional aims' but are not very credible from the research point of view (p. 217). This chapter concludes with 'life itself', in other words, 
various nuances of the coexistence of the Association's members, from friendship to conflict.

The fourth part opens with a perspective that is obvious to some extent, since this is a country where at one time Louis XIV purposely harnessed art to promote the greatness of his state. We learn how the political aim of the French authorities to be a world power influenced the decision to support higher education establishments that were willing to admit foreign students; this is an excellent opportunity to show how far the fate of art and artists depends on the political will and ambition of those in power. And so the author presents the role played by a number of institutions in making Paris the "world music university'. Against this background it is easier to understand the phenomenon of Nadia Boulanger, who later became almost symbolic of the presence of Polish musicians in Paris. However, Boulanger did not teach just Poles, nor even the Americans who arrived at her door in droves. The French also obtained musical education because, as Suchowiejko tells us, 'The music teaching on offer [...] was [...] adapted to the needs of the consumer. Musical competence constituted [...] an element of general education, useful socially or as a source of income' (p. 275). Reading these words one cannot help but reflect with sadness that in Warsaw, Kraków or Poznan it is generally acceptable to declare oneself to be deaf to music, even in intellectual circles. Finally, we come to the last chapter, and find there the already mentioned behind-the-scenes politics in the area of culture; this is probably the first (certainly very rare in our literature) analysis of this aspect in relation to musical life. The name of Robert Brussel, probably unknown to most readers, provides the point of departure for presenting the activities of Association française d'action artistique. This chapter has an abundance of detail showing the organisation of such work, and so is worth recommending to all those engaged in the promotion of art. We also find there references to Towarzystwo Szerzenia Sztuki Polskiej wśród Obcych [Society for Spreading Polish Art among Foreigners] - the prototype of today's Adam Mickiewicz Institute. It also played an important part in making Parisian audiences aware of the fact that Polish music did not begin and end with Chopin.

The 150-page appendix which closes the 530 pages of this volume offers some key texts which throw light on the issues involved, translated by Małgorzata Gamrat, Barbara Kochan and Renata Suchowiejko. This anthology begins with articles relating directly to Paderewski and devoted to his performative art and to his person. There are Aleksander Tansman essays about Polish music and critical reviews after the premiere of Szymanowski's Harnasie. Finally we have a review of documents from the archive of the Association of Young Polish Musicians. And, having finished reading Musical Paris à la polonaise during the interwar period we can look at some 70 reproductions of concert programmes and posters documenting the repertoire, scorings, and even customs (the first poster immediately next to the time of the concert has the remark: 'très précises').

I have mentioned the very apt choices regarding the sequence of the issues discussed. I can add that the language of the book also deserves praise; it is clear and readable. And, speaking personally, I appreciate the fact that Suchowiejko resists romantic myths and, for example, acknowledges that talent and person- 
ality are not enough to achieve artistic and financial success. That depends on a myriad of external factors, such as the infrastructure of musical life, high standard of education, influential concert agencies as well as a few others - and these are the factors she investigates. Many observations in this book testify to the author's down-to-earth perspective on life (including musical life) and the people who create it (this is particularly apparent in the chapter on the Association).

The pleasure of reading is enhanced by the design, starting with the drawing by Zofia Stryjeńska on the cover which matches the contents to perfection, through the rich iconography, to the easy-to-read formatting. Muzyczny Paryż à la polonaise w okresie międzywojennym. Artyści - wydarzenia - konteksty is above all a valuable source of information for a historian of music, but at the same time such an attractive presentation of an important moment in the history of our musical culture that it can be recommended to friends as well. If they like reading about musicians that should be enough - familiarity with the mysteries of the sonata form or the principles of counterpoint is not required. 